\title{
Prevalence of Abnormal Haemoglobins in Pulmonary Tuberculosis in Three Different Ethnic Groups
}

\author{
N. SAHA \\ From the Department of Physiology, Faculty of Medicine, University of Singapore, Singapore 3
}

There is evidence from the study of twins (Lenz, 1963; Carter, 1969) of a genetic predisposition to certain diseases, in particular pulmonary tuberculosis. But there are apparently no published reports of an association of pulmonary tuberculosis and ABO-Rh blood groups, haemoglobin, and immunoglobin types. Saha and Banerjee (1968) could not establish an association between $\mathrm{ABO}-\mathrm{Rh}$ blood groups and the presence of pulmonary tuberculosis, though there was a lower incidence of $O$ group persons among Chinese patients. No relation was found between pulmonary tuberculosis and glucose6-phosphate dehydrogenase deficiency in any of the three ethnic groups studied (Saha, 1969).

The results of these observations prompted the use of another genetic marker, namely abnormal haemoglobin gene, to study the genetic predisposition to pulmonary tuberculosis. Inquiries have been made in the past by other workers into a possible association of A-S and A-C traits with pulmonary tuberculosis, but the results were inconclusive (Table I). In most of the studies the numbers of patients were too few to provide acceptable information, and in none of these studies were different ethnic groups investigated along with simultaneous investigation of controls. Inquiries on different ethnic groups are needed

Received 15 September 1969. because of the possibility that a racial factor over and above common genetic predisposition may produce variability in susceptibility to disease.

It was thought worth while to study the association of haemoglobin mutant gene in three different ethnic groups in an attempt to discover whether this genetic mutant and racial type indicate predisposition to the development of pulmonary tuberculosis.

\section{Materials and Methods}

The subjects were confirmed cases of pulmonary tuberculosis comprising 1963 Chinese, 181 Malays, and 100 Indians. These patients, who were adults of both sexes, were attending the Singapore Anti-Tuberculosis Association (SATA) clinic for treatment. For comparison, 1453 healthy adults of both sexes of the same agegroup as the patients, comprising 1102 Chinese, 308 Malays, and 43 Indians, were also investigated. These healthy subjects were attending SATA for routine clinical, radiological, and haematological examinations.

Details of the method of collecting blood have been given elsewhere (Saha, 1969). Red cells were washed three times with $0.9 \%$ sodium chloride solution, haemolysed with a volume of distilled water equal to that of the packed cell volume; half this volume of toluene was then added to the haemolysed solution. After vigorous shaking for 10 minutes, the mixture was centrifuged at 3000 r.p.m. for half an hour to give a clear haemolysate at the bottom. Haemoglobin types were separated by paper electrophoresis at 250 volts for 8 hours at $8-10^{\circ} \mathrm{C}$.

TABLE I

INCIDENCE OF ABNORMAL HAEMOGLOBINS IN PULMONARY TUBERCULOSIS

\begin{tabular}{|c|c|c|c|c|}
\hline Series & $\begin{array}{l}\text { No. of } \\
\text { Patients }\end{array}$ & $\begin{array}{c}\text { No. with } \\
\text { Abnormal } \\
\text { Haemoglobins }\end{array}$ & Genotype & $\begin{array}{c}\text { Control } \\
(\%)\end{array}$ \\
\hline $\begin{array}{l}\text { Dolgopol and Stitt (1929) } \\
\text { Weiss and Stecher (1952) } \\
\text { Rosenblum et al. (1955) } \\
\text { Ryan et al. (1960) } \\
\text { Coulter (1965) } \\
\text { Kher and Grover (1969) } \\
\text { Present study }\end{array}$ & $\begin{array}{r}77 \\
150 \\
200 \\
310 \\
220 \\
100 \\
2244\end{array}$ & $\begin{array}{l}4(5 \cdot 2 \%) \\
19(12 \cdot 6 \%) \\
15(7 \cdot 5 \%) \\
28(9 \cdot 0 \%) \\
8(4 \cdot 0 \%) \\
0 \\
16(0.71 \%)\end{array}$ & $\begin{array}{c}\text { AS } \\
\text { AS } \\
\text { AS } \\
\text { AS } \\
\text { AC } \\
\text { AS } \\
\text { AE, AD, and } \\
\text { AH }\end{array}$ & $\begin{array}{l}6 \cdot 5 \\
5 \cdot 3 \\
8 \cdot 0 \\
6 \cdot 7 \\
1 \cdot 5-3 \\
1 \cdot 79\end{array}$ \\
\hline
\end{tabular}


TABLE II

DISTRIBUTION OF ABNORMAL HAEMOGLOBINS IN PULMONARY TUBERCULOSIS COMPARED TO NORMALS

\begin{tabular}{|c|c|c|c|c|c|c|c|c|}
\hline \multirow{2}{*}{$\begin{array}{l}\text { Ethnic } \\
\text { Group }\end{array}$} & \multicolumn{3}{|c|}{ Tuberculosis Patients } & \multicolumn{3}{|c|}{ Normal Controls } & \multicolumn{2}{|r|}{ Vella $(1960,1962)$} \\
\hline & No. & $\begin{array}{l}\text { Prevalance } \\
\text { of Abnormal } \\
\text { Haemoglobins }\end{array}$ & $\begin{array}{l}\text { Haemoglobin } \\
\text { Genotype }\end{array}$ & No. & $\begin{array}{l}\text { Prevalance } \\
\text { of Abnormal } \\
\text { Haemoglobins }\end{array}$ & $\begin{array}{l}\text { Haemoglobin } \\
\text { Genotype }\end{array}$ & No. & $\begin{array}{l}\text { Prevalance of Abnormal } \\
\text { Haemoglobins } \\
\text { and Genotype }\end{array}$ \\
\hline Chinese & 1963 & $4(0.20 \%)$ & $\begin{array}{l}\mathrm{AE}-2 \\
\mathrm{AH}-1 \\
\mathrm{AI}-1\end{array}$ & 1102 & $7(0.64 \%)$ & AE-7 & 7101 & 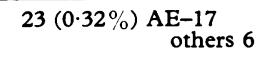 \\
\hline Malay & 181 & $11\left(6.08^{\circ}\right)$ & AE-10 & 308 & $17(5 \cdot 52 \%)$ & $\begin{array}{l}A E-16 \\
A H-1\end{array}$ & & $168(4.55 \%) \underset{\text { others } 10}{\mathrm{AE}-158}$ \\
\hline Indian & 100 & $1(1 \cdot 00 \%)$ & AD-1 & 43 & $2(4 \cdot 60 \%)$ & AD-1 & 2117 & $25(1 \cdot 18 \%) \underset{\substack{\text { AD-1 } \\
\text { AE-8 } \\
\text { others } 6}}{2}$ \\
\hline Total & 2244 & $16\left(0 \cdot 71_{0}^{\circ}\right)$ & & 1453 & $26(1 \cdot 79 \%)$ & & 12899 & $216(1 \cdot 67 \%)$ \\
\hline
\end{tabular}

using Whatman 3 MM paper, in horizontal tanks filled with barbitone buffer at $p \mathrm{H} 8.6$ and ionic strength $0 \cdot 025 \mathrm{M}$. When an abnormal haemoglobin was detected by paper electrophoresis at $p \mathrm{H} 8 \cdot 6$, the presence was confirmed by separate electrophoresis on cellulose acetate strips using barbitone buffer of $p H 8.6$ and ionic strength $0.05 \mathrm{M}$ at 200 volts for 30 minutes. Haemoglobins $\mathrm{H}$ and $\mathrm{I}$ were differentiated by repeating the paper electrophoresis at $p H$ 6.5. At this $p H$, haemoglobin I moved towards the negative pole and could therefore be differentiated from haemoglobin $\mathrm{H}$ which remained at the origin. An AE standard was run simultaneously as a control with each series of tests. Further identification was attained by Itano's (1953) solubility test in phosphate buffer which served to differentiate haemoglobin $\mathrm{D}$ from $\mathrm{S}$, sickling test, and the presence of haemoglobin $\mathrm{H}$ inclusion bodies (Jonxis and Huisman, 1958; Lehmann and Huntsman, 1966).

\section{Results}

The results are presented in Table II. The prevalance of abnormal haemoglobins in Chinese patients was less than that in control $\left(\chi^{2}=3.671\right.$ d.f. $)$; the significance of the differences was more obvious when $\mathrm{E}$ haemoglobin was considered alone $\left(\chi^{2}=\right.$ 6.861 d.f.). There was no significant difference between the prevalance of abnormal haemoglobin in Malay and in Indian patients compared to normals.

\section{Discussion}

An association between resistance to pulmonary tuberculosis and the presence of $\mathrm{O}$ blood group was again found in Chinese patients (Saha and Banerjee, 1968). The present results of the controls differ slightly from those of Vella $(1960,1962)$. The discrepancy may have been due to differences in sampling and methodology. The prevalence of abnormal haemoglobins even in Vella's series (1960) differed from one locality to another. Besides, the present-day population of Singapore may be different in composition from that of a decade ago.

The present results revealed a significant difference in the prevalance of abnormal haemoglobins among Chinese with pulmonary tuberculosis compared with controls. Failure to show a comparable difference between patients and controls among Malays and Indians supports the view that a racial factor may influence predisposition to pulmonary tuberculosis. This is compatible with an ethnic influence in the aetiology of duodenal ulcer as indicated by variable levels of significance in White and Negro patients in relation to association between ABO blood groups and duodenal ulcer (Roberts, 1959). But as the numbers of Malay and Indian patients were small further investigation on this point is required.

\section{Summary}

A total of 2244 patients of different ethnic groups suffering from pulmonary tuberculosis was investigated for prevalance of abnormal haemoglobins. For comparison, 1453 healthy subjects of comparable age, sex, and ethnicity were also investigated.

Chinese with pulmonary tuberculosis had a lower prevalence of abnormal haemoglobins than Chinese who were free of the disease. This difference was not found in Malays or Indians, but this may have been due to the small numbers investigated.

Sincere thanks are due to Dr. N. C. Sengupta, Medical Director of SATA, for permission to carry out this study, and to Professor G. R. Wadsworth for valuable criticism and help in the preparation of the manuscript. The author gratefully acknowledges the technical help of 
Mr. Chan Ban Kiat and the secretarial help of Mr. Ronald Young.

\section{REFERENCES}

Carter, C. O. (1969). An ABC of medical genetics. I. Genetics in the aetiology of disease. Lancet, 1, 1014-1016.

Coulter, W. W., Jr. (1965). Incidence of haemoglobin 'C' trait in tuberculous Negroes. Fournal of the Louisiana State Medical Society, 117, 242-244.

Dolgopol, V. B., and Stitt, R. H. (1929). The sickle cell phenomenon in tuberculosis patient. American Review of Tuberculosis and Pulmonary Diseases, 19, 454-460.

Itano, H. A. (1953). Solubilities of naturally occurring mixtures of human hemoglobin. Archives of Biochemistry and Biophysics, 47, 148-159.

Jonxis, J. H. P., and Huisman, T. H. J. (1958). A Laboratory Manual of Abnormal Haemoglobins. Blackwell Scientific Publications, Oxford.

Kher, M., and Grover, S. (1969). Glucose-6-phosphate-dehydrogenase deficiency in leprosy. Lancet, $1,1318$.

Lehmann, H., and Huntsman, R. G. (1966). Man's Haemoglobins. North-Holland Publishing Company, Amsterdam.
Lenz, W. (1963). Medical Genetics, p. 168. The University of $\overparen{P}$ Chicago Press, Chicago.

Roberts, J. A. F. (1959). Some association between blood groups and disease. British Medical Bulletin, 15, 129-133.

Rosenblum, R., Kabakow, B., Lichtman, H. C., and Lyons, H. A. (1955). Sickle cell trait and disease in pulmonary tuberculosis. Archives of Internal Medicine, 95, 540-542.

Ryan, T. J., O'Connor, T. F., McCurdy, P. R., and Katz, S. (1960). Sickle cell trait and tuberculosis. American Review of Respiratory Diseases, 81, 564-549.

Saha, N. (1969). Incidence of G6PD deficiency in patients of three different ethnic groups suffering from pulmonary tuberculosis. fournal of Medical Genetics, 6, 292-293.

, and Banerjee, B. (1968). Incidence of $A B O$ and $R h$ blood groups in pulmonary tuberculosis in different ethnic groups. Fournal of Medical Genetics, 5, 306-307.

Vella, F. (1960). Abnormal haemoglobin variants in 10,441 Chinese subjects. Acta Haematologica, 23, 393-397.

- (1962). Abnormal haemoglobins, thalassaemia and erythrocyte glucose-6-phosphate-dehydrogenase deficiency in Singapore and Malaya. Oceania, 32, 219-225.

Weiss, W., and Stecher, W. (1952). Tuberculosis and the sickle- . cell trait. Archives of Internal Medicine, 89, 914-922. 